\title{
Mineralization of Soil Organic Nitrogen under Waterlogged Conditions in Relation to Other Properties of Tropical Rice Soils
}

\section{K. L. Sahrawat}

The International Rice Research Institute, Los Baños, Laguna, Philippines; present address: International Crops Research Institute for the Semi-Arid Tropics (ICRISAT), ICRISAT Patancheru P.O; A.P. 502324, India.

\begin{abstract}
The mineralizable nitrogen pool in wetland rice soils plays a dominant role in the nitrogen nutrition of rice even in fertilized paddies. There is a lack of information on how different soil properties affect ammonification of organic nitrogen in wetland rice soils. Surface samples of 39 diverse Philippine soils representing a wide range of $\mathrm{pH}$, organic matter and texture were studied to determine the relationships between ammonification of organic nitrogen and soil properties.

Simple correlation analysis showed that ammonium production was correlated highly significantly with total nitrogen $\left(r=0.94^{* *}\right)$, organic carbon $\left(r=0.91^{* *}\right)$ and $\mathrm{C} / \mathrm{N}$ ratio $\left(r=-0 \cdot 46^{* *}\right)$, but it was not significantly correlated with cation exchange capacity, clay or $\mathrm{pH}$. Multiple regression analayses showed that organic matter (organic carbon and total nitrogen) accounted for most of the variation in mineralizable nitrogen. These results suggest that organic carbon content is a good index of mineralizable nitrogen in tropical wetland rice soils.
\end{abstract}

\section{Introduction}

Mineralization of soil organic nitrogen is very important for the nutrition of wetland rice because studies using ${ }^{15} \mathrm{~N}$ labelled fertilizer, which permit distinction between soil and fertilizer nitrogen, have clearly shown that rice obtains half to two-thirds of its nitrogen requirement from the soil mineralizable nitrogen pool even in a well-fertilized paddy (Broadbent 1978; IAEA 1978).

Mineralization of organic nitrogen is affected by several environmental factors, the most important being temperature and moisture regimes. Studies made at the International Rice Research Institute (IRRI) showed that mineralization of organic nitrogen in four soils under anaerobic incubation increased with the increase in temperature from $15^{\circ}$ to $45^{\circ} \mathrm{C}$ (IRRI 1974). Similarly, the importance of temperature on nitrogen mineralization in paddy soils has been brought out by studies made in Japan and elsewhere (Kai et al. 1969; Ponnamperuma 1972; Onikura et al. 1975; Yoshino and Dei 1977; Broadbent 1979). The influence of moisture regime is critical for mineralization of soil nitrogen because the pattern of mineral nitrogen release is affected by soil drying (Shiga and Ventura 1976). Soil drying prior to flooding enhances mineralization of organic nitrogen (Shioiri et al. 1941; Shioiri 1948; Ventura and Watanabe 1978; Sahrawat 1980b). Sahrawat (1981) reported that mineralization of organic nitrogen was very rapid in four Philippine organic soils when they were air-dried, but there was virtual absence of ammonification in the continuously wet Histosols. 
In a recent review, Broadbent (1979) has discussed the range of soil and climatic factors that affect mineralization of organic nitrogen in paddy soils, and concluded that the mineralization process is affected by soil temperature, moisture regime, organic amendments, wetting and drying, nature and amount of organic matter and

Table 1. Analyses of soils used

\begin{tabular}{|c|c|c|c|c|c|c|c|c|}
\hline $\begin{array}{l}\text { S } \\
\text { No. }\end{array}$ & $\begin{array}{l}\text { oil } \\
\text { Texture }\end{array}$ & $\begin{array}{c}\mathrm{pH} \\
(1: 1)\end{array}$ & $\begin{array}{c}\text { Org. C } \\
(\%)\end{array}$ & $\begin{array}{c}\text { Total N } \\
(\%)\end{array}$ & $\mathrm{C} / \mathrm{N}$ & $\begin{array}{c}\text { CEC } \\
\text { (m.e. } / 100 \mathrm{~g})\end{array}$ & $\begin{array}{l}\text { Clay } \\
(\%)\end{array}$ & $\begin{array}{c}\operatorname{Min} . N^{\mathrm{A}} \\
(\mu \mathrm{g} / \mathrm{g})\end{array}$ \\
\hline 1 & Clay & $4 \cdot 5$ & $1 \cdot 54$ & $0 \cdot 17$ & $9 \cdot 0$ & $23 \cdot 5$ & 62 & 63 \\
\hline 2 & Clay & $4 \cdot 3$ & $1 \cdot 94$ & $0 \cdot 18$ & $10 \cdot 8$ & $16 \cdot 5$ & 71 & 75 \\
\hline 3 & Clay & $5 \cdot 3$ & $1 \cdot 48$ & $0 \cdot 16$ & $9 \cdot 2$ & $30 \cdot 3$ & 57 & 73 \\
\hline 4 & Clay & $4 \cdot 4$ & $1 \cdot 98$ & $0 \cdot 20$ & $9 \cdot 9$ & $30 \cdot 5$ & 53 & 82 \\
\hline 5 & Clay & $5 \cdot 4$ & $2 \cdot 44$ & $0 \cdot 31$ & $7 \cdot 9$ & $36 \cdot 2$ & 49 & 332 \\
\hline 6 & Clay & $5 \cdot 8$ & $3 \cdot 36$ & $0 \cdot 33$ & $10 \cdot 2$ & $43 \cdot 0$ & 60 & 279 \\
\hline 7 & Silty clay loam & $5 \cdot 5$ & $5 \cdot 46$ & $0 \cdot 60$ & $9 \cdot 1$ & $44 \cdot 3$ & 22 & 428 \\
\hline 8 & Silty clay loam & $5 \cdot 6$ & $4 \cdot 76$ & $0 \cdot 48$ & $9 \cdot 9$ & $40 \cdot 9$ & 24 & 315 \\
\hline 9 & Clay & $4 \cdot 7$ & $2 \cdot 42$ & $0 \cdot 26$ & $9 \cdot 3$ & $36 \cdot 8$ & 74 & 147 \\
\hline 10 & Silty clay loam & $6 \cdot 4$ & $1 \cdot 76$ & $0 \cdot 18$ & $9 \cdot 8$ & $29 \cdot 3$ & 33 & 49 \\
\hline 11 & Clay loam & $7 \cdot 4$ & $1 \cdot 97$ & $0 \cdot 18$ & $10 \cdot 9$ & $35 \cdot 9$ & 33 & 103 \\
\hline 12 & Silty clay loam & $5 \cdot 5$ & $2 \cdot 05$ & $0 \cdot 16$ & $12 \cdot 8$ & $37 \cdot 7$ & 27 & 118 \\
\hline 13 & Silty clay & $6 \cdot 9$ & 1.69 & $0 \cdot 16$ & $10 \cdot 6$ & $36 \cdot 2$ & 47 & 50 \\
\hline 14 & Clay & $5 \cdot 1$ & 0.93 & 0.08 & $11 \cdot 6$ & $25 \cdot 5$ & 56 & 32 \\
\hline 15 & Clay & $4 \cdot 8$ & 0.95 & 0.08 & $11 \cdot 9$ & $23 \cdot 9$ & 55 & 36 \\
\hline 16 & Clay & $7 \cdot 0$ & $1 \cdot 89$ & $0 \cdot 16$ & $11 \cdot 8$ & $45 \cdot 4$ & 68 & 47 \\
\hline 17 & Clay & $6 \cdot 4$ & $0 \cdot 83$ & 0.08 & $10 \cdot 4$ & $35 \cdot 5$ & 60 & 24 \\
\hline 18 & Clay & $4 \cdot 8$ & $1 \cdot 42$ & $0 \cdot 15$ & $9 \cdot 5$ & $18 \cdot 2$ & 68 & 39 \\
\hline 19 & Clay & $5 \cdot 6$ & $1 \cdot 15$ & $0 \cdot 10$ & $11 \cdot 5$ & $51 \cdot 3$ & 68 & 23 \\
\hline 20 & Clay & $6 \cdot 6$ & $2 \cdot 14$ & $0 \cdot 21$ & $10 \cdot 2$ & $50 \cdot 8$ & 68 & 52 \\
\hline 21 & Silty clay loam & $7 \cdot 2$ & $0 \cdot 84$ & 0.07 & $12 \cdot 0$ & $39 \cdot 5$ & 41 & 17 \\
\hline 22 & Silty loam & $7 \cdot 5$ & 0.63 & 0.06 & $10 \cdot 5$ & $35 \cdot 5$ & 23 & 17 \\
\hline 23 & Silty loam & $7 \cdot 9$ & $0 \cdot 63$ & $0 \cdot 06$ & $10 \cdot 5$ & $35 \cdot 5$ & 23 & 20 \\
\hline 24 & Silty clay & $5 \cdot 7$ & $1 \cdot 03$ & 0.09 & $11 \cdot 4$ & $36 \cdot 1$ & 48 & 24 \\
\hline 25 & Silty clay loam & $7 \cdot 0$ & $0 \cdot 91$ & $0 \cdot 08$ & $11 \cdot 4$ & $42 \cdot 3$ & 44 & 21 \\
\hline 26 & Silty clay & $5 \cdot 7$ & $0 \cdot 83$ & 0.06 & $13 \cdot 8$ & $33 \cdot 8$ & 47 & 19 \\
\hline 27 & Silty clay loam & $4 \cdot 8$ & $1 \cdot 11$ & 0.07 & $15 \cdot 9$ & $27 \cdot 0$ & 42 & 19 \\
\hline 28 & Silty clay loam & $6 \cdot 1$ & $1 \cdot 09$ & $0 \cdot 08$ & $13 \cdot 6$ & $25 \cdot 8$ & 30 & 24 \\
\hline 29 & Clay & $4 \cdot 9$ & $1 \cdot 63$ & $0 \cdot 13$ & $12 \cdot 5$ & $44 \cdot 3$ & 62 & 41 \\
\hline 30 & Silt loam & $5 \cdot 2$ & $0 \cdot 72$ & 0.06 & $12 \cdot 0$ & $9 \cdot 9$ & 13 & 26 \\
\hline 31 & Silt loam & $6 \cdot 5$ & $1 \cdot 89$ & $0 \cdot 16$ & $11 \cdot 8$ & $20 \cdot 2$ & 24 & 54 \\
\hline 32 & Clay loam & $6 \cdot 5$ & $0 \cdot 75$ & $0 \cdot 08$ & $9 \cdot 4$ & $30 \cdot 5$ & 35 & 20 \\
\hline 33 & Sandy loam & $4 \cdot 7$ & 0.65 & 0.06 & $10 \cdot 8$ & $8 \cdot 6$ & 15 & 22 \\
\hline 34 & Loam & $5 \cdot 0$ & $0 \cdot 65$ & 0.06 & $10 \cdot 8$ & $7 \cdot 0$ & 12 & 41 \\
\hline 35 & Loam & $4 \cdot 9$ & $0 \cdot 77$ & 0.07 & $11 \cdot 0$ & $8 \cdot 6$ & 19 & 23 \\
\hline 36 & Silty clay loam & $5 \cdot 3$ & $1 \cdot 36$ & $0 \cdot 11$ & $12 \cdot 4$ & $30 \cdot 5$ & 32 & 44 \\
\hline 37 & Clay & $5 \cdot 3$ & $1 \cdot 30$ & $0 \cdot 11$ & $11 \cdot 8$ & $33 \cdot 5$ & 51 & 41 \\
\hline 38 & Silty clay & $6 \cdot 5$ & $1 \cdot 50$ & $0 \cdot 13$ & $11 \cdot 5$ & $34 \cdot 3$ & 42 & 28 \\
\hline 39 & Silty clay & $5 \cdot 3$ & $2 \cdot 50$ & $0 \cdot 25$ & $10 \cdot 0$ & $40 \cdot 9$ & 50 & 169 \\
\hline
\end{tabular}

A Ammonium nitrogen released under anaerobic incubation of soils at $30^{\circ} \mathrm{C}$ for 2 weeks.

clay content. It also becomes evident from this review that the relationships between ammonification of organic nitrogen and soil properties have not been clearly established, and this is reflected in a considerable degree of uncertainty with simple and rapid predictive tests for characterizing potentially mineralizable nitrogen. 
Limited studies of the relationship between mineralizable nitrogen and soil properties indicate that mineralizable nitrogen is related to organic matter and total nitrogen (Lopez and Galvez 1958; Onikura et al. 1975), cation exchange capacity (CEC) and clay content (Onikura et al. 1975). It has also been recognized that liming of acid soils improves nitrogen availability to rice probably due to enhanced mineralization of soil nitrogen (Ponnamperuma 1958; Borthakur and Mazumdar 1968). But the effects of liming may also be attributed partly to alleviation of toxicities of nutrients such as iron, and improvement in the availability of other nutrients due to a rise in soil $\mathrm{pH}$ which affects rice growth. It is, however, difficult to establish clearly the effects of soil $\mathrm{pH}$ on mineralization of organic nitrogen from such studies. In a recent study of two acid sulfate soils ( $\mathrm{pH} 3 \cdot 4$ and 3.7), Sahrawat $(1980 b)$ reported that ammonification of soil organic nitrogen was active in these soils. The aim of the work reported here was to study the relationships between mineralizable nitrogen and soil properties using 39 Philippine rice soils having a wide range in properties.

\section{Materials and Methods}

\section{Solls}

The soils used were surface $(0-15 \mathrm{~cm})$ samples collected shortly before the study from different rice growing parts of the Philippines. The soil samples were air dried and ground to pass through a $2-\mathrm{mm}$ sieve before use. Table 1 shows that the soils used in the study differed markedly in $\mathrm{pH}$ (4.3-7.9), organic carbon $(0 \cdot 63-5.46 \%)$,

$(7 \cdot 9-15 \cdot 9)$ and clay content $(12-71 \%)$.

For soil analyses reported in Table 1, pH was measured (1:1 soil to water) by a glass electrode, organic carbon and total nitrogen were determined by the methods of Walkley and Black (1934) and Bremner (1965a) respectively. CEC and particle size analysis were done as described by Chapman (1965) and Day (1965) respectively.

\section{Incubation Method}

The incubation method used was adapted from that described by Waring and Bremner (1964). The major modification in the method was that, instead of directly distilling the incubated soil samples with $\mathrm{MgO}$, they were first extracted with $2 \mathrm{~N} \mathrm{KCl}$ and the filtered extracts of soils were used for determination of ammonium released, as suggested by Sahrawat and Ponnamperuma (1978).

Soil $(10 \mathrm{~g})$ was placed in a test tube $(16$ by $2 \mathrm{~cm})$ containing about $15-20 \mathrm{ml}$ of distilled water to give a standing water layer of $2-3 \mathrm{~cm}$. The soil was slowly and carefully transferred to the test tube containing water to minimize trapping of air. The test tube was covered with aluminium foil and incubated at $30^{\circ} \mathrm{C}$ for 2 weeks in an anaerobic incubator.

After incubation, the soil samples were extracted with $2 \mathrm{~N} \mathrm{KCl}$, keeping the final soil to $\mathrm{KCl}$ solution ratio of 1:10. A 20-ml aliquot of the filtered extract was distilled with $\mathrm{MgO}$ to determine the ammonium nitrate released (Bremner 1965b). All the determinations were made at least in duplicate.

\section{Results and Discussion}

The amounts of $\mathrm{NH}_{4}^{+}$released during anaerobic incubation of the soils varied between 17 and $428 \mu \mathrm{g} \mathrm{g}^{-1}$ soil (Table 1).

Table 2 shows that mineralizable nitrogen released was correlated highly significantly with both organic carbon $\left(r=0 \cdot 91^{* *}\right)$ and total nitrogen $\left(r=0 \cdot 94^{* *}\right)$. Mineralizable nitrogen was also correlated highly significantly but negatively with $\mathrm{C} / \mathrm{N}$ ratio $\left(r=-0 \cdot 46^{* *}\right)$, but was not significantly correlated with $\mathrm{pH}, \mathrm{CEC}$ or clay content. These results are in agreement with the observations made by Lopez and Galvez (1958), who reported that organic matter and total nitrogen were related with the mineralization of organic nitrogen under submerged conditions. Onikura 
et al. (1975) also reported that ammonium production in wetland soils was related to total nitrogen content.

Summary of the data on the distribution of mineralizable nitrogen in the 39 soils further brings out its association with organic carbon and total nitrogen (Table 3 ). While 24 soil samples having total nitrogen varying between 0.06 and $0 \cdot 16 \%$ released less than $50 \mu \mathrm{g}$ ammonium nitrogen/g soil, on the other hand four soil samples containing total nitrogen greater than $0 \cdot 31 \%$ produced more than $200 \mu \mathrm{g}$ ammonium nitrogen/g soil. Soil samples having total nitrogen contents varying

Table 2. Correlations between mineralizable nitrogen and other soil properties $(n=39)$

\begin{tabular}{lclc}
\hline Soll property & $\begin{array}{c}\text { Correlation } \\
\text { coefficient }(r)\end{array}$ & Soll property & $\begin{array}{c}\text { Correlation } \\
\text { coefficient }(r)\end{array}$ \\
\hline Total N & $0.94^{* *}$ & CEC & $0.30 \mathrm{n} \mathrm{s}$ \\
Organice & $0.91^{* *}$ & pH & $-0.14 \mathrm{n} \mathrm{s}$ \\
C/N ratio & $-0.46^{* *}$ & Clay & $-0.05 \mathrm{n} \mathrm{s}$ \\
\hline
\end{tabular}

${ }^{* *} P=0 \cdot 01 ;$ n.s, not significant

between $0 \cdot 16$ and $0 \cdot 26 \%$ produced ammonium nitrogen ranging from 50 to 200 $\mu \mathrm{g} / \mathrm{g}$ soil. Since organic carbon and total nitrogen content are indexes of organic matter content, the highly significant simple correlations between mineralizable nitrogen and organic carbon content and total nitrogen content (Table 2) suggest that organic matter accounted for most of the variation in the mineralizable nitrogen in the soils studied. Organic carbon was very highly correlated with total nitrogen $\left(r=0.99^{* *}\right)$, which is reflected in very high significant correlations between mineralizable nitrogen and total nitrogen, and organic carbon.

Table 3. Distribution of mineralizable nitrogen in 39 rice soils in relation to total nitrogen and organic carbon content

\begin{tabular}{cccc}
\hline $\begin{array}{l}\text { Mineralization } N \\
(\mu / \mathrm{g} \text { dry soll })\end{array}$ & $\begin{array}{c}\text { No of } \\
\text { samples }\end{array}$ & $\begin{array}{c}\text { Associated soll properties } \\
\text { Ootal N }(\%)\end{array}$ & Organic C (\%) \\
\hline$<50$ & 24 & $0 \cdot 06-016$ & $0 \cdot 63-1 \cdot 15$ \\
$50-100$ & 7 & $0 \cdot 16-021$ & $1 \cdot 48-2 \cdot 14$ \\
$100-200$ & 4 & $0 \cdot 16-0 \cdot 26$ & $1 \cdot 97-2 \cdot 50$ \\
$>200$ & 4 & $0 \cdot 31-0 \cdot 60$ & $2 \cdot 44-5 \cdot 46$ \\
\hline
\end{tabular}

Mineralization of organic nitrogen occurs under a wide range of $\mathrm{pH}$, and the results of the present study support this conclusion. As noted in the introduction, in an earlier communication I reported that though ammonification of soil nitrogen occurred in two acid sulfate soils ( $\mathrm{pH} 3 \cdot 4$ and $3 \cdot 7$ ), both under aerobic and anaerobic conditions, nitrification was absent under aerobic conditions that stimulate nitrification (Sahrawat 1980c). Moraghan and Patrick (1974), who studied the release of ammonium in the Louisiana soil system at $\mathrm{pH}$ values of 5, 6 or 7 during anaerobic incubation, reported that the contents of ammonium nitrogen were initially reduced at $\mathrm{pH} 5$ and 6 , but the effect of $\mathrm{pH}$ was small by 30 days. But perhaps the differential salt contents in the soil resulting due to addition of $\mathrm{NaOH}$ and $\mathrm{HCl}$ to maintain different $\mathrm{pH}$ might have also affected the ammonification as suggested by these authors (Moraghan and Patrick 1974). These 
results indicate that ammonification is adapted in soils with a wide range in $\mathrm{pH}$. The low $\mathrm{pH}$ conditions in wetland acid soils create conditions conducive for iron toxicity which limits rice growth, but once the iron concentration falls below toxic levels, these soils release enough ammonium to support a good crop of rice (Sahrawat 1980a).

Onikura et al. (1975) reported that mineralization of organic nitrogen under lowland paddy soil conditions was related positively to total nitrogen, CEC and clay content of soils. Observations made by Broadbent (1979) indicate that the relationship of mineralizable nitrogen with clay content in the study by Onikura et al. (1975) reflected the high organic matter content of the fine-textured soils. It thus appears that organic matter controlled ammonium production under lowland conditions in the soils studied by Onikura et al. because of association among clay, organic matter and CEC.

Stepwise multiple regression analyses of the mineralizable nitrogen (Min. N) with various combinations of soil properties showed that $88 \cdot 3 \%$

mineralizable nitrogen was accounted for by total nitrogen alone by the following equation:

Min. $N=-44 \cdot 4+792 \cdot 3($ Total $N)$.

While organic carbon alone accounted for $82 \cdot 8 \%$ of the variability, a combination of organic carbon and total nitrogen accounted for $89 \cdot 4 \%$ variability in the mineralizable nitrogen by the following equation:

$$
\text { Min. } \mathrm{N}=-29 \cdot 9+1336 \cdot 1(\text { Total } \mathrm{N})-61 \cdot 0(\text { organic } \mathrm{C}) \text {. }
$$

Most variability $\left(R^{2}=91.8 \%\right)$ was accounted by the following regression equation, which was only slightly better than the variability accounted by total nitrogen alone:

$$
\text { Min. } \begin{aligned}
\mathrm{N}= & -68 \cdot 8+1969 \cdot 6(\text { Total } \mathrm{N})-128 \cdot 8(\text { organic } \mathrm{C})+9.9(\mathrm{C} / \mathrm{N}) \\
& -9 \cdot 2(\mathrm{pH})+0 \cdot 88(\mathrm{CEC})-0 \cdot 75(\text { clay }) .
\end{aligned}
$$

A multiple regression analysis of $\mathrm{CEC}, \mathrm{pH}$ and clay on mineralizable nitrogen (excluding total nitrogen and organic carbon) accounted only for $37.4 \%$ variability.

$$
\text { Min. } \mathrm{N}=340 \cdot 2+7 \cdot 03(\mathrm{CEC})-6 \cdot 34(\mathrm{pH})-2 \cdot 8 \text { (clay). }
$$

It is, however, noteworthy that, though simple correlation analyses showed that $\mathrm{pH}, \mathrm{CEC}$ and clay were not significantly correlated to mineralizable nitrogen (Table 2), multiple regression showed that $\mathrm{pH}, \mathrm{CEC}$ and clay had significant effects on mineralizable nitrogen in different soils. However, both simple correlation as well as multiple regression analysis showed that total nitrogen and organic carbon (components of organic matter) accounted for the most variability in the mineralizable nitrogen in the 39 soils studied in the present study.

The results of this study suggest that organic matter content (measured by organic carbon and total nitrogen) is a good index for predicting the pool of potential mineralizable nitrogen in wetland rice soils.

\section{Acknowledgments}

I thank the International Rice Research Institute for financial support and Dr F. N. Ponnamperuma, Principal Soil Chemist, IRRI, for helpful comments during planning work and preparation of the manuscript. 


\section{References}

Borthakur, H. P., and Mazumdar, N. N. (1968). Effect of lime on nitrogen avallability in paddy soll. J Indian Soc. Soll Scl. 16, 143-7.

Bremner, J. M. (1965a). Total nitrogen. In 'Agronomy 9, Methods of Soll Analysis'. pp. 1149-78. (Ed. C. A. Black.) (Am. Soc. Agron.: Madison, Wisc.)

Bremner, J. M. (1965b) Inorganic forms of nitrogen. In 'Agronomy 9, Methods of Soll Analysis'. pp. 1179-237 (Ed C. A Black.) (Am. Soc Agron.. Madıson, Wisc)

Broadbent, F. E. (1979). Transformations of soll nitrogen. In 'Soils and Rice'. pp. 543-59. (International Rice Research Instıtute: Los Baños, Laguna, Philıppınes)

Broadbent, F. E. (1978). Mineralization of organic nitrogen in paddy sols. In 'Nitrogen and Rice'. pp. 105-118. (International Rice Research Institute: Los Baños, Laguna, Philippines.)

Chapman, H. D. (1965). Cation-exchange capacity. In 'Agronomy 9, Methods of Soil Analysis'. pp. 891-901. (Ed. C. A. Black.) (Am. Soc. Agron.: Madison, Wisc.)

Day, P. R. (1965). Hydrometer method of particle size analysis In Agronomy 9, Methods of Soil Analysis' pp 562-66 (Ed C A Black) (Am Soc Agron· Madıson, Wisc)

IAEA (1978). Isotope studies on rice fertilization. Joint FAO/IAEA Div. Atomic Energy Food Agric., Tech. Rep Ser. No 181 (International Atomic Energy Agency Vienna)

IRRI (1974). Int Rice Res. Inst. Ann. Rep 1973. (Los Baños, Laguna, Phılıppines.)

Kai, H., Ahmad, A., and Harada, T (1969). Factors affectıng immobilization and release of nitrogen and chemical characteristics of the nitrogen newly immobilized. 1. Effect of temperature on immobilization and release of nitrogen in soll. Soll Scl. Plant Nutr. (Tokyo) 15, 207-13.

Lopez, A. B., and Galvez, N. L. (1958). The mineralization of the organic matter of some Philippine solls under submerged conditions. Phllppine Agric. 42, 281-90.

Moraghan, J. T., and Patrick, W H. Jr. (1974). Selected metabolic process in a submerged soll at controlled pH values. Trans 10th Int. Congr. Soll Sci., Vol II, pp. 264-69 (Moscow).

Onıkura, Y., Yoshino, T., and Maeda, K (1975). Mineralization patterns of soll nitrogen during the growth of rice plant. J Scl. Soll Manure (Japan) 46, 255-9.

Ponnamperuma, F N (1958). Lime as a remedy for a physiological disease of rice associated with excess iron. Int Rice Comm. Newsl. 7, 10-13.

Ponnamperuma, F. N. (1972). The chemistry of submerged soils. Adv. Agron. 24, 29-96.

Sahrawat, K. L. (1980a) Nitrogen supplyıng ability of some Philıppne rıce soils. Plant Soll 55, 181-7.

Sahrawat, K. L. (1980b). Soil and fertilizer nitrogen transformations under alternate flooding and drying mo1sture regimes. Plant Soll 55, 225-33.

Sahrawat, K. L. (1980c). Nitrogen mineralization in acid sulfate soils. Plant Soll 57, 143-146.

Sahrawat, K. L (1981). Ammonification in air-dried tropical lowland Histosols. Soll Biol. Brochem. 13, $323-4$.

Sahrawat, K. L., and Ponnamperuma, F. N. (1978). Measurement of exchangeable $\mathrm{NH}_{4}^{+}$in tropical rice soils. Soll Scl. Soc. Am. J. 42, 282-3.

Shiga, H., and Ventura, W. (1976). Nitrogen supplying ability of paddy solls under field conditions in the Philippines. Soll Scl. Plant. Nutr. (Tokyo) 22, 287-99.

Shiorri, M. (1948). Effect of drying in paddy field during fallow period. Bull. Agric. Exp. Stn Min. Agric. (Japan) 64, 1-24.

Shiorri, M., Aomine, S., Uno, Y., and Harada, T. (1941). Effect of air-drying of paddy soll (in Japanese). J. Scl. Soll Manure (Japan) 15, 331-3.

Ventura, W., and Watanabe, I. (1978). Dry season soil conditions and soll nitrogen availability to wet season wetland rıce. Soll Scl. Plant Nutr. (Tokyo) 24, 535-45.

Walkley, A., and Black, I. A. (1934). An examınation of the Degtjareff method for determining soll organic matter and a proposed modification of the chromic acid titration method. Soll Sci. 37, 29-38.

Warıng, S. A., and Bremner, J M. (1964). Ammonium production in soll under water logged conditions as an index of nitrogen avallability. Nature (London) 201, 951-2

Yoshıno, T., and Dei, Y (1977). Predıctıon of nitrogen release in paddy soils by means of the concept of effective temperature. J. Central Agric. Exp. Stn (Japan) 25, 1-62. 